\title{
Medicinal Plants of Tecopatlán, Jalisco, Mexico: Description of the Uses and Environmental Availability
}

\author{
Adrian Gutiérrez Alonso ${ }^{1}$, Elizabeth Anne Olson ${ }^{2 *}$, Judith Cevallos Espinosa ${ }^{1}$, and Jesús Juan Rosales Adame ${ }^{1}$ \\ ${ }^{1}$ Natural Resources and Ecology Department, University of Guadalajara, South Coast Campus, Autlán, Mexico. ${ }^{2}$ Department \\ of History, Sociology, and Anthropology, Southern Utah University, Cedar City, USA. \\ "elizabetholson@suu.edu
}

\begin{abstract}
The non-Indigenous, mestizo, ejido (communal agricultural land) Tecopatlán is located in the municipality of Autlán de Navarro, Jalisco, in the influence zone of the Sierra de Manantlán Biosphere Reserve (SMBR). The primary purpose of this research was to characterize traditional knowledge of medicinal plants held by residents of Tecopatlán in relationship to the land use patterns of the ejido. We interviewed 34 people, selected by convenience sampling, to identify their knowledge of medicinal plants and the local environment. Informants reported a total of 72 medicinal species, belonging to 45 botanical families, distributed across 67 genera. Of the plants recorded, 55 were exogenous and 19 were native species. Informants were surveyed regarding common ailments and the plants used to treat those ailments. The most common ailments reported include diabetes, coughs, kidney problems, nerves, stomach pain, insomnia, cancer, and stroke. The land use patterns described by community members reveal specific areas of the local environment that have the most commonly used medicinal plants.
\end{abstract}

Received June 27, 2019

OPEN ठACCESS

Accepted March 16, 2020

DOI 10.14237/ebl.11.1.2020.1614

Published September 29, 2020

Keywords Traditional ecological knowledge, Medicinal plants, Ethnobotany, Mexico

Copyright (C) 2020 by the author(s); licensee Society of Ethnobiology. This is an open-access article distributed under the terms of the Creative Commons Attribution-NonCommercial 4.0 International Public License (https://creativecommons.org/licenses/by-nc/4.0), which permits non-commercial use, distribution, and reproduction in any medium, provided the original author and source are credited.

\section{Introduction}

Culture plays an important role in attempts to conserve natural environments and promote sustainable development. Human societies actively modify their environments, and likewise environments impact and help shape human societies. Traditional knowledge refers to the accumulation of empirical knowledge, obtained through observations, experiences, and practical activities, and has developed over time allowing Indigenous societies and horticulturalists to survive, and even flourish, in diverse environments. Such knowledge is often called traditional ecological knowledge (TEK) and has been studied by ethnobiologists including Toledo (1992:6), who defined the field as "the study of relations between cosmos (beliefs and symbolic representations), corpus (environmental awareness) and praxis (the behaviors that lead to the appropriation of nature)." Much of the TEK and landscape features that we encounter today are products of these long histories and processes of humans' interaction with the surrounding environment.

Ethnobiologists are interested in the ways that humans interact with their environments, including their perceptions of the environment, their own conservation priorities, and uses of natural resources. The environment, in this analytic context, should be understood as a biocultural landscape, made up of biotic and abiotic factors, creating a complex system of interactions and flows of energy (Zonneveld 1989). Biocultural landscapes are comprised of both internal and external relationships, so understanding the factors that affect those relationships is important for conservation or development programs.

Today, contemporary Mexican communities in rural areas are not Indigenous communities alone. Many are also mestizo. The individuals who live in rural areas may not have the same historical-cultural relationship to the landscapes that they occupy, but this does not mean that they do not value the land or 


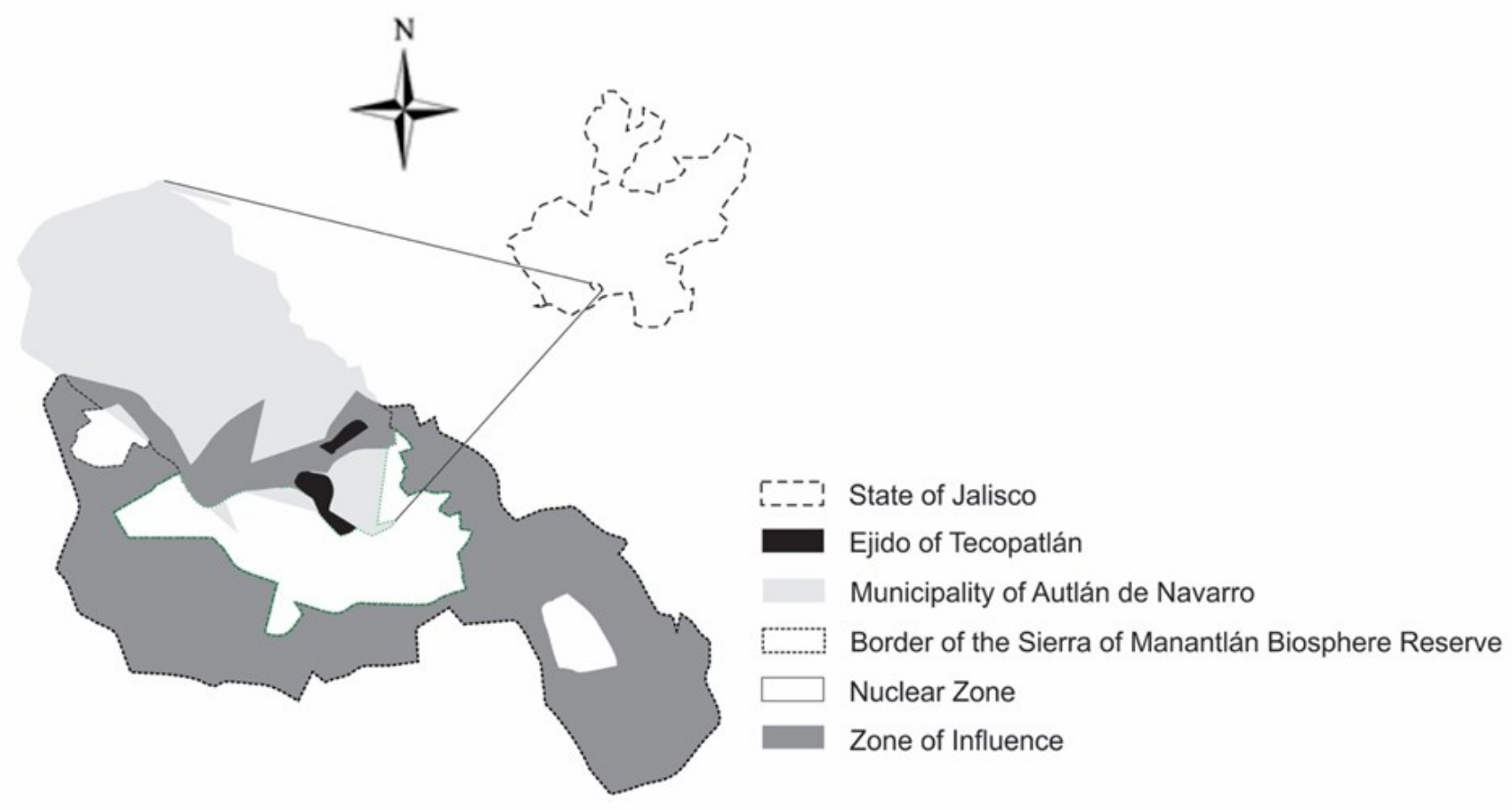

Figure 1 Location of the ejido of Tecopatlan and Sierra of Manantlán Biosphere Reserve.

have unique knowledge about the sustainable management of rural areas where they reside. In this era of globalization and the rapid transmission of ideas and resources, we must acknowledge the multidirectional flows of TEK, as well as the accompanying flow of people. In Mexico, a lack of viable economic opportunities in rural communities often leads to rural-to-urban migration (Wilson 2010). Furthermore, Cano and colleagues (2016) point out that scholars have shown the links between migration and the alteration of local ecosystems, including a decrease in ecosystem integrity.

In the Sierra of Manantlán region of Mexico, traditional knowledge has been eroding due to processes of acculturation and out-migration. These processes are byproducts of governmental policies in the region that do not adequately consider cultural heritage and local values associated with TEK and plants (Benz et al. 1994; Olson 2014). National policies are not alone responsible for the social and cultural changes in Mexico, since globalization puts incredible pressure on rural and small-scale landholders to produce high yields with low overhead costs. When faced with global market competition, migration to local, regional, and even international urban centers becomes a viable alternative.

Through the political, social, and economic processes associated with colonization, modernization, and globalization in Mexico, much of the TEK has been eroded (Gomez 1993). A clear example of this is the loss of Indigenous languages, which comes about with acculturation and the extensive outmigration that frequently accompanies government policies and programs which are not in tune with the needs of Indigenous communities (Benz et al. 1994; Olson 2014). The loss of TEK is facilitated by the outmigration from rural areas to urban regions, changes in consumption patterns (such as use of drugs and alcohol; Zitnow 1990), and habitat destruction and modification.

In this context, it is important to identify and support TEK to inform communities' use and management of natural resources. Documentation of TEK is an essential part of the process of improving conservation and development programs for Mexico, as it provides critical information and promotes awareness of TEK through the research process (Ituarte Lima 2007; Jardel and Benz 2004). While 
research has been conducted to demonstrate the wealth of TEK held in Indigenous communities, we know considerably less about TEK in rural mestizo communities of Mexico (Casas et al. 2016).

The research presented in this article was carried out in the mestizo town of Tecopatlán, Jalisco, which is located in the influence zone of the Sierra of Manantlán Biosphere Reserve (SMBR). The SMBR has explicit goals related to natural resource conservation, community development, and the safeguarding of local cultural heritage (Olson 2014). The purpose of this research was to document TEK and land use strategies in Tecopatlán, and through the research process augment awareness of pathways to sustainable development that are community-based in this region of Mexico. The research is communitybased, included the community throughout the stages of the research process, sought an equitable relationship between researchers and participants, and was reflective of a community need to identify current land use strategies and TEK (Olson 2014). Being a community-based research project, we sought to produce information on land use patterns that can inform future land management strategies. In this article, we report and describe the TEK held by community members in Tecopatlán in relationship to land use patterns.

\section{Research Site}

The ejido of Tecopatlán is located approximately 20 $\mathrm{km}$ southeast of the city of Autlan, which is the municipal seat of Autlán de Navarro, Jalisco, within the SMBR. It is a community that is not Indigenous, but rather of families who identify as mestizo. Tecopatlán is located in the influence zone of the SMBR, and also in the municipality of Autlán - a major urban market center. This means that there is simultaneously pressure to conserve biodiversity and work toward community development, whilst community members are also implicated in the market economy of Autlán (Figure 1).

The vegetation in Tecopatlán is characterized by oak forest (55\%) and pine-oak forest (32\%) (Rzedowski 1978; Vazquez et al. 1995). The climate ranges from warm-subtropical to temperate and semihumid climate zones, and the average annual rainfall ranges from $900 \mathrm{~mm}$ in drier parts of the north, to $1800 \mathrm{~mm}$ in areas of higher elevation (Vazquez et al. 1995).

The total population of the ejido of Tecopatlán is
58 people. The main road is unpaved, and there is no public transportation. The primary economic activities in the ejido are livestock tenure and seasonal agriculture for sale and consumption within the household. Public services were severely limited at the time of the research, with only electricity being available in the ejido and no access to potable water or a sewage system. Due to the remote location of the ejido, there was no local school, and children travelled to a neighboring community (El Chante), where the nearest primary school was located (Instituto Nacional de Estadística y Geografía 2010).

\section{Materials and Methods}

Prior to beginning the data collection, the permission of the local governing body and the community was obtained. The Consulate of the Tecopatlán ejido granted permission to conduct the research, after which an informational meeting was held for the entire community. The primary data collection was conducted by Gutiérrez (2015), who held the community meeting to explain the purposes of this research, including the type of data that would be collected, and to answer questions from the community members. There were two primary components of data collection: (1) semi-structured interviews and guided hikes with informants to identify TEK and record knowledge of medicinal plants, and (2) a participatory workshop in the community wherein data were collected to characterize the landscape zones and their uses in the ejido.

Participants were recruited by convenience and snowball sampling since we were interested in finding key informants who do have knowledge of medicinal plants. Key informants were recruited by word-ofmouth at the introductory community meeting to which the entire community was invited, where Gutierrez made a presentation about this research project. Later, convenience sampling was used but Gutierrez found greater success recruiting participants by snowball sampling, taking referrals to individuals who were suggested by interviewees because of their reported knowledge of medicinal plants.

Qualitative data were obtained via semi-structured interviews that lasted between fifteen and thirty minutes. Guided hikes were frequently undertaken by Gutierrez after the semi-structured interview, adding between forty-five minutes to two hours, depending on the distance hiked to find the plants. Interviewees were asked, "What medicinal plants do you know?," 
Table 1 Local Classification of environmental conditions and soil type of each space. TDF, Tropical deciduous forest; GF, Gallery forest; OF, Oak Forest; PF, Pine Forest.

\begin{tabular}{llllll}
\hline Zone & Altitudinal Range $(\mathbf{m})$ & Vegetation Characteristic & Vegetation Type & Soil Type & Environmental Condition \\
\hline Low & $1000-1300$ & Thin & TDF & Sandy & Hot \\
& & & GF & Beach & Wet-Hot \\
Half & $1400-2000$ & Thick & OF & Compact & Temperate \\
& & & OF-PF & Mud & Cold \\
High & $2000-2500$ & PF & Mud & Cold-Wet \\
\hline
\end{tabular}

which was followed-up with questions about whether or not they had used each plant, and if so, for what purpose. Then, at the conclusion of the semistructured interview, Gutierrez went on a hike with the interviewee during which the interviewee would identify specific plants that had already been mentioned during the interview. Not all participants agreed to go on the guided hike. Sometimes, during the walk, interviewees were able to identify more plants than previously mentioned, adding additional information regarding the names and uses of plants. Some plant samples were collected during the guided hikes for the purpose of identification at the Botany Laboratory at the University of Guadalajara, South Coast Campus (CUCSUR). There were no voucher specimens collected for the purposes of this research (due to limited local capacity and resources for housing them).

All of the interview data were entered into a database, which was used to generate a complete list of the plants identified, the common and scientific names, and the reported uses. Other individual characteristics of each informant were also recorded in the database and were used to generate descriptive statistics regarding the distribution of medicinal plant knowledge in the community of Tecopatlán.

During the semi-structured interviews, the various uses of local flora, landscape management strategies, and landscape usage were also recorded. Interviewees were asked to characterize the different areas of land that are found throughout the ejido and to characterize it and the primary uses for each land area. No maps were used during this time, but informants used geographical and landmark references to describe different terrains in the ejido. Later, after collecting the initial information about the different zones from community members, a participatory community workshop was held (to which the entire community was invited) and ten adults attended. During the participatory community workshop, a map was sketched on a drawing board and community members delineated the various types of landscape zones found throughout the ejido, which was also linked to the potential uses of each zone (Table 1). There were five principal landscape zones identified by the community members: (1) household gardens, (2) rangelands, (3) slash and burn fields in the forest, (4) agricultural fields, and (5) firebreaks, or buffer zones between landscape types.

\section{Results}

Altogether, 34 community members participated in this study, of which 13 were women and 21 were men, with an average age of 52.4 years. Almost all of the women (12) are housewives, and only one woman works in retail; most of the men (17) are farmers. Most of the study participants (29) are from Tecopatlán, and only 5 were born elsewhere.

A total of 72 plants were reported for having medicinal or healing uses by the study participants (Table 2). When asked how frequently they use medicinal plants, the main response was once a month $(29 \%)$, followed by daily (21\%), and weekly $(12 \%$; Figure 2).

Of the 72 species recorded, $54 \%$ are herbaceous, $38 \%$ are trees, and $8 \%$ are shrubs (Table 3). In

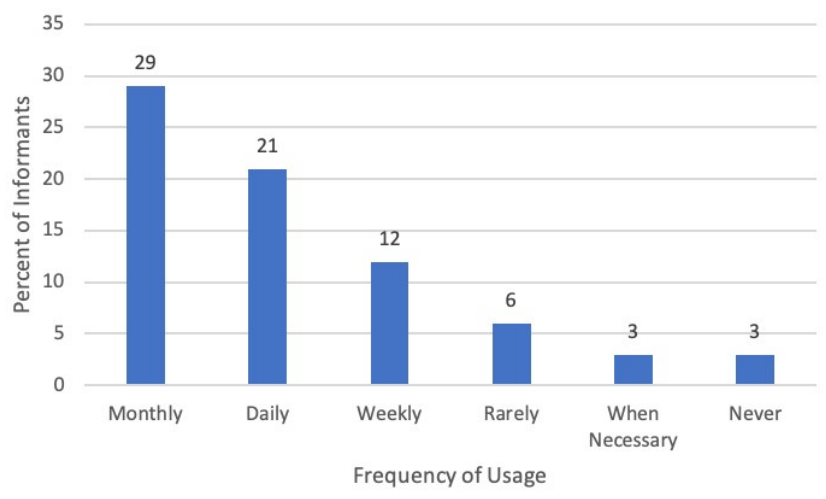

Figure 2 Frequency of use of medicinal plants by informant. 
Table 2 List of 72 medicinal plants identified by informants with scientific names.

\begin{tabular}{|c|c|c|c|}
\hline Common Name (Spanish) & Familia & Scientific Name & No. of Informants Listing Plant \\
\hline Salvia & Labiatae & Hyptis albida & 16 \\
\hline Conguerán & Phytolaccaceae & Phytolacca icosandra & 12 \\
\hline Campanillo & Rubiaceae & Hintonia latiflora & 11 \\
\hline Cola de caballo & Equisetaceae & Equisetum arvense & 9 \\
\hline Garañona & Labiatae & Satureja macrostema & 9 \\
\hline Chintuza & Asteraceae & Guardiola tulocarpus & 8 \\
\hline Encino colorado & Fagaceae & Quercus ssp. & 8 \\
\hline Madroño & Ericaceae & Arbustus xalapensis & 7 \\
\hline Hierbabuena & Lamiaceae & Mentha piperita & 6 \\
\hline Espinosilla & Polemoniaceae & Loeselia mexicana & 6 \\
\hline Gordolobo & Asteraceae & Gnaphalium bourgovii & 4 \\
\hline Caña de indio & Costaceae & Costus pictus & 4 \\
\hline Capulin & Rosaceae & Prunus serotina Ehrenb. subsp. capuli & 4 \\
\hline Cuatalaca & Salicaceae & Caesaria arguta & 4 \\
\hline Flor de tila o Sirimo & Theaceae & Ternstroemia lineata & 4 \\
\hline Lechuguilla & Agavaceae & Agave maximiliana & 3 \\
\hline Hierba del arlomo & Asteraceae & Baccharis trinervis & 3 \\
\hline Peyote de cerro & Asteraceae & Roldana sessilifolia & 3 \\
\hline Guamuchil & Fabaceae & Pithecellobium dulce & 3 \\
\hline Huevos de zopilote & Solanaceae & Solanum ferrugineum & 3 \\
\hline Palo santo & Anacardiaceae & Amphipterygium adstringens & 2 \\
\hline Estafiate & Asteraceae & Artemisia ludoviciana subsp. & 2 \\
\hline Palo mulato & Euphorbiaceae & Jatropha platyphylla & 2 \\
\hline Tabardillo & Fabaceae & Calliandra ssp. & 2 \\
\hline Aguacate & Lauraceae & Persea americana & 2 \\
\hline Guayaba & Myrtaceae & Psidium guajava & 2 \\
\hline Fresno & Oleaceae & fraxinus udhei & 2 \\
\hline Jenjibre & Zingiberaceae & Zingiber officinale & 2 \\
\hline Palo Maria & Clusiaceae & Calophyllum brasiliense & 2 \\
\hline Cirguelilla/Ciruela & Anacardiaceae & Spondias purpurea & 1 \\
\hline Cola de iguana o Espada & Asparagaceae & Sansevieria trifasciata & 1 \\
\hline Palo rosita & Apocynaceae & Stemmadenia tomentosa & 1 \\
\hline Prodigiosa & Asteraceae & Brickellia cavanillesii & 1 \\
\hline Retama o Amargosilla & Asteraceae & Calea urticifolia & 1 \\
\hline Arnica & Asteraceae & Heterotheca ssp. & 1 \\
\hline Hierba del venado & Asteraceae & Porophyllum punctatum & 1 \\
\hline Gabardillo & Asteraceae & Piqueria triflora & 1 \\
\hline Anis & Asteraceae & Tagetes filifolia & 1 \\
\hline Begonia & Begoniaceae & Begonia ssp. & 1 \\
\hline Berro Palmita & Boraginaceae & Phacelia platycarpa & 1 \\
\hline Papaya & Caricaceae & Carica papaya & 1 \\
\hline Tuna blanca & Cactaceae & Opuntia ssp. & 1 \\
\hline Epazote & Chenopodiaceae & Chenopodium graveolens & 1 \\
\hline Laurel & Clethraceae & Clethra rosei & 1 \\
\hline Cazahuate (or Bejuco) & Convolvulaceae & Ipomoea bracteata & 1 \\
\hline Siempre viva de castilla & Crassulaceae & Sedum ssp. & 1 \\
\hline Berro & Cruciferae & Rorippa nasturtium-aquaticum & 1 \\
\hline Cedro & Crupressaceae & Cupressus ssp. & 1 \\
\hline Huizache & Fabaceae & Acacia farnesiana & 1 \\
\hline
\end{tabular}

(continued on next page) 


\begin{tabular}{|c|c|c|c|}
\hline Common Name (Spanish) & Familia & Scientific Name & No. of Informants Listing Plant \\
\hline Encino blanco & Fagaceae & Quercus castanea & 1 \\
\hline Nogal & Juglandaceae & Juglans major & 1 \\
\hline Oregano & Lamiaceae & Origanum vulgare & 1 \\
\hline Mirto & Lamiaceae & Salvia microphyla & 1 \\
\hline Albahaca & Lamiaceae & Ocimun basilicum & 1 \\
\hline Laurelillo & Lauraceae & Litsea glaucescens & 1 \\
\hline Tepehuaje & Leguminosae & Lysiloma acapulcense & 1 \\
\hline Ortiga o Quemadora & Loasaceae & Gronovia scandens & 1 \\
\hline Guacima & Malvaceae & Guazuma ulmifolia & 1 \\
\hline Neem & Meliaceae & Azadirachta indica & 1 \\
\hline Barbudillo & Moraceae & Dorstenia drakena & 1 \\
\hline Suelda & Opiliaceae & Agonandra racemosa & 1 \\
\hline Pasiflora o Granada china & Passifloraceae & Passiflora edulis & 1 \\
\hline Hierba del zorrillo & Phytolaccaceae & Petiveria alliacea & 1 \\
\hline Hierba del golpe & Plantaginaceae & Scoparia dulcis & 1 \\
\hline Lanten & Plantaginaceae & Plantago australis & 1 \\
\hline Tachinole & Plumbaginaceae & Plumbago scandens & 1 \\
\hline Tejocote & Rosaceae & Crataegus pubescens & 1 \\
\hline Nispero & Rosaceae & Eriobotrya japonica & 1 \\
\hline Zapote blanco & Rutaceae & Casimiroa sapota & 1 \\
\hline Ruda & Rutaceae & Ruta graveolens & 1 \\
\hline Tomatillo & Solanaceae & Solanum ferrugineum & 1 \\
\hline Sabila & Xanthorrhoeaceae & Aloe vera & 1 \\
\hline
\end{tabular}

addition, $74 \%$ are wild and native, $22 \%$ are introduced cultigens, and $4 \%$ are wild and introduced.

The medicinal plants that were most frequently used by informants were sage (Hyptis albida), button pokeweed (Phytolacca icosandra), yellow quina or copalchi (Hintonia latiflora), té de monte (tea of the mountain, Satureja macrostema), chintuza (Guardiola tulocarpus), and horsetail (Equisetum spp.). We also had informants report the medical problems they encountered. Of the health problems most commonly encountered, we asked informants specifically which ones were treated with medicinal plants. The most commonly reported ailments treated with the various medicinal plants included: diabetes, cough, kidney problems, nerves, stomach pain, insomnia, cancer, and strokes.

Regarding the parts of the plant that are used, informants reported that the leaves are used from
$56 \%$ of the species, bark is primarily used from $19 \%$ of the species, the flower is used from $18 \%$ of the species, and for $18 \%$ of the species, the whole plant is used (Figure 3). The most common methods of preparation were infusions (water-based) and macerations.

The other primary area of data collection occurred through a participatory community workshop, during which landscape zones were identified and characterized. Through this participatory workshop, it became clear that community members are acutely aware of their surroundings, as they were able to describe the geomorphological units (i.e., the terrain), as well as the classification of coverage and vegetation characteristics (Figure 4). The community workshop process is shown in Figure 5, depicting the dynamic process of discussion and consensus building that took place.

Table 3 Distribution of species by vegetation types.

\begin{tabular}{lllllll}
\hline & Oak Forest & Gallery Forest & Pine Forest & Orchard & Tropical Deciduous Forest & \% \\
\hline Herbaceous & 10 & 5 & 1 & 13 & 10 & 54 \\
Trees & 8 & 4 & 4 & 5 & 7 & 38 \\
Shrubs & 1 & 0 & 1 & 0 & 4 & 8 \\
\hline
\end{tabular}




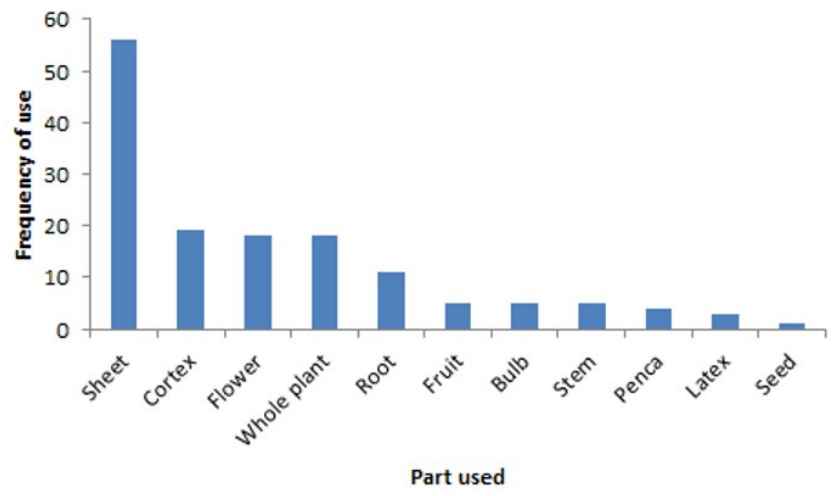

Figure 3 Parts of the medicinal plant used by informants.

During the community workshops, we also sought to identify the primary zones where the medicinal plants were collected and learn how those landscape zones are managed (Gutiérrez et al. 2015).

\section{Characterizations of Landscape Zones and Management}

As depicted in Figure 4, land in the lowlands or grasslands is used primarily for household gardens. In the household gardens, foods and some medicinal plants to be consumed within the household are cultivated. The proximity of these gardens to the house make them perfect for growing a variety of fruits, cooking herbs, medicinal herbs, ornamental plants, and shade trees. Of the medicinal plants grown in household gardens, peppermint (Mentha piperita) was the most common.

Rangelands at lower elevation are primarily used for cattle grazing and may or may not be arable. Rangelands in lower elevations are plots left to fallow or which have been temporarily converted into pasture areas. For example, as the rainy season begins - but before the farmer plants - cattle may be brought into a low area rangeland to graze and thereby aid in the preparation (clearing) of the plot for planting. Similarly, after harvest when the dry season begins, the farmer may reintroduce cattle to consume the surplus of the harvest.

There are also rangelands in the mid-range elevation areas where naturally occurring grasses can often endure for several months after the beginning of the rainy season. Cattle can stay at the mid-range elevation for approximately eight months, during which time farmers continually manage the herds.

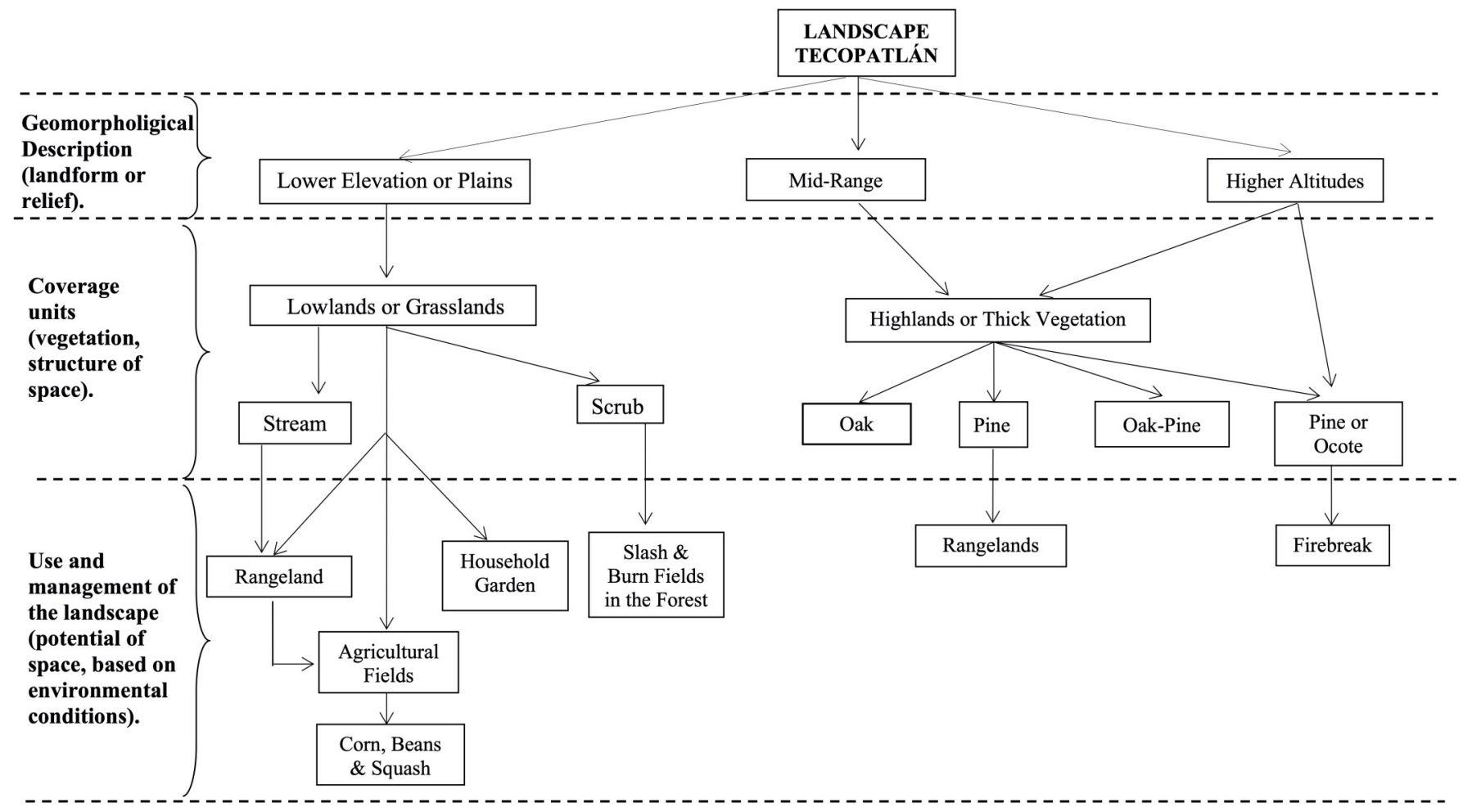

Figure 4 Schematic representation of the distribution of natural resources and productive area of each passage of the ejido Tecopatlán. Diagram based on Gerritsen (2010). 


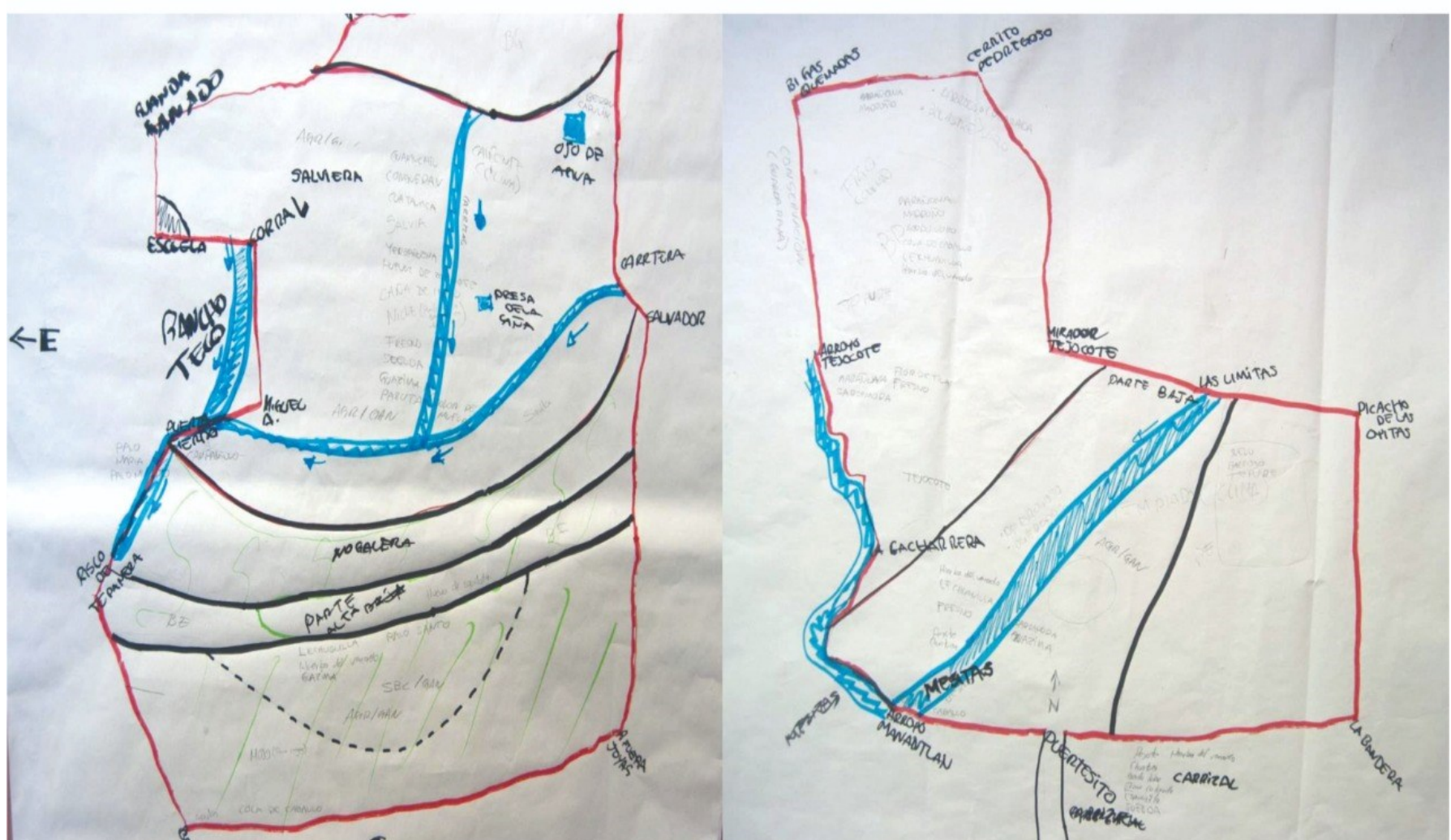

Figure 5 Photos of the participatory workshop to characterize the landscape zones and management strategies in Tecopatlán. Photos courtesy of A. Gutiérrez.

Fallow cultivation fields are part of the rotating seasonal agricultural system where "slash and burn" is utilized. In Tecopatlán, the fallow fields are found primarily on the slopes of the hillsides nearest the populated central area. Milpa is commonly practiced, wherein corn, beans, and squash are grown together in the field. After harvesting, animals (particularly cattle) are brought in to graze on the leftover plant materials. Agricultural plots are located in the lowlands, and are also utilized to grow milpa, of which some of the produce is sold, but most is consumed within the household.

Finally, the firebreak, or buffer zone, is located in the highlands amidst pine or mixed forests. This landscape zone is managed by community members following the recent guidance of the National Commission on Forests (CONAFOR). CONAFOR has embarked on national programs that pay for environmental services and have instructed community members to make strategic lines on the hillside and remove vegetative litter and undergrowth to make a barrier to stop wildfires.

\section{Discussion}

In this study, we found that participants were very familiar with the landscape zones, including the use and management of the different landscape types. Furthermore, we found that individuals held a considerable amount of medicinal plant knowledge when compared to prior studies in this community and region (Benz et al. 2000). It seems logical that older individuals would carry more medicinal plant knowledge since they have had more cumulative life experience. In Tecopatlán, the older generation is more likely to have lived an agrarian lifestyle (depending directly on the land for subsistence) for their entire life.

De Niz (1989) recorded 135 species in the same region of the SMBR, with species from the taxonomic families Labiatae, Leguminosae, and Compositae being the most common. De Niz also found that the tropical deciduous forest, temperate forests, and household gardens were where the highest number of medicinal species were found. By comparison, we documented 72 medicinal plant species, and the three 
families that were most common were Asteraceae, Lamiaceae, and Rosaceae. The landscape types with the highest number of medicinal plants that we recorded match what De Niz reported. The correlation between the types of landscape and vegetation, between our study and De Niz's, could be because individuals tend to visit those landscape zones most frequently. Benz and colleagues (1994) showed that these particular vegetation areas have higher plant diversity. Additionally, in Tecopatlán, these ecosystems are closer to the town.

Our study findings also resonate with those of García Valdez and Flores (2008), who reported the most common illnesses for which medicinal plants were used included diarrhea, cough, stomach pains, fever and indigestion. The present study reflected the same illnesses, with the exception of fever and indigestion, but the inclusion of bruises and cancer. Hyptis albida was the species most frequently common and curing most diseases in both studies our study and that of Garcia and Flores (2008).

The data reported by De Niz (1989) and ParedesFlores and colleagues (2007) indicated the household garden as the source of the largest proportion of medicinal plants species. However, our findings indicate that the household garden was the third-most common landscape area that sourced medicinal plants.

\section{Conclusions}

Studies such as this, which document traditional knowledge, are key components of strategies to help conservation and promote the sustainable use of natural resources. Our findings contribute to the other existing data on TEK in the SMBR that supports the importance of community-based conservation strategies. By incorporating community members in the process of identifying management strategies for different landscape zones, the Biosphere Reserve will be able to fulfill the broad mission for which it was formed: advancing sustainable community development, supporting Indigenous cultural heritage, and promoting ecological conservation.

\section{Acknowledgments}

The authors would like to recognize the contributions of our friend and colleague, Francisco Javier Santana Michel, who passed away before this article was written and submitted for press. Mr. Santana Michel gave extensive assistance in identifying the plants for this project, as well as other guidance regarding the trajectory of the fieldwork. The authors are very grateful to the community of Tecopatlán, who have participated in this research through their generosity of time, knowledge, and spirit.

\section{Declarations}

Permissions: Local community was consulted and agreed to participate (verbal assent).

Sources of funding: None declared.

Conflicts of Interest: None declared.

\section{References Cited}

Benz, B. F., F. J. Santana M., R. Pineda L., J. Cevallos E., L. Robles H., and D. De Niz L. 1994. Characterization of Mestizo Plant Use in the Sierra de Manantlán, Jalisco-Colima, México. Journal of Ethnobiology 14:23-41.

Benz, B. F., J. Cevallos E., F. Santana-Michel, J. Rosales A., and S. Graf-Montero. 2000. Losing Knowledge About Plant Use in the Sierra de Manantlán Biosphere Reserve, Mexico. Economic Botany 54:183-191. DOI:10.1007/BF02907821.

Cano, M., B. De la Tejera, A. Casas, L. D. L. Barrientos, and R. García-Barrios. 2016. Conocimientos Tradicionales y Prácticas de Manejo del Huerto Familiar en Dos Comunidades Tlahuicas del Estado de México, México. Revista Iberoamericana de Economía Ecológica 25:81-94.

Casas, A., J. Vázquez, and R. Lira. 2016. Mexican Ethnobotany: Interactions of People and Plants in Mesoamerica. Springer Press, New York.

De Niz, L. D. 1989. Contribución al Conocimiento de las Plantas Medicinales de la Sierra de Manantlán, Jalisco. Bachelor's thesis, Department of Biology and Environment, Universidad de Guadalajara, Guadalajara, Mexico.

García Valdez, A., and I. Flores Elías. 2008. Plantas Medicinales en Cuatro Comunidades del Ejido Ayotitlán, Municipio de Cuautitlán, Jalisco. Bachelor's thesis, Department of Biology and Environment, Universidad de Guadalajara de la Costa Sur, Autlán, Mexico.

Gerritsen, P. R. W. 2010. Perspectivas Campesinas Sobre el Manejo de Los Recursos Naturales: Un Acercamiento Teórico-Empírico. In Abordajes Regionales: Formas de Concebir, Maneras de Interpretar, edited by G. Hernández and L. E. Castañeda R., pp. 
29-44. Universidad de Guadalajara de la Costa Sur, Autlán, Mexico.

Gutiérrez, A. A. 2015. Plantas Medicinales de Tecopatlán, Municipio de Autlán, Jalisco: Descripción del Uso y su Entorno Natural. Bachelor's thesis, Department of Natural Resources and Agriculture, Universidad de Guadalajara de la Costa Sur, Autlán, Mexico.

Gutiérrez, A. A., J. C. Espinosa, E. A. Olson, J. J. R. Adame, and F. J. S. Michel. 2015. Medicinal Plants of Tecopatlán, Jalisco, Mexico: Description of the Uses and Environmental Availability. Poster presented at the 38 th Annual Meeting of the Ethnobiology Society. Santa Barbara, CA. Available at: https://ethnobiology.org/conference/ abstracts/38. Accessed June 13, 2017.

Instituto Nacional de Estadística y Geografía. 2010. Censo de Población y Vivienda. Available at https://www.inegi.org.mx/programas/ccpv/2010/ default.html. Accessed on June 8, 2014.

Ituarte Lima, C. 2007. Conocimientos Tradicionales de la Biodiversidad y Derechos de los Pueblos Indígenas. Report of Instituto Nacional de Ecología, México.

Jardel, F., J. Cevallos E., and B. F. Benz. 2004. El Conocimiento Tradicional del Manejo de los Recursos Naturales y la Diversidad Biológica. In El Patrimonio Nacional de México, II, edited by E. Florescano, pp. 193-231. Fondo de Cultura y Económica, Consejo Nacional para la Cultura y Las Artes, México.
Olson, E. A. 2014. Indigenous Knowledge and Development: Liveliboods, Health Experiences, and Medicinal Plant Knowledge in a Mexican Biosphere Reserve. Lexington Books, Lanham, MD.

Paredes-Flores, M., R. Lira Saade, and P. D. Davila Aranda. 2007. Estudio Etnobotánico de Zapotitlan Salinas, Puebla. Acta Botanica Mexicana 79:13-61.

Rzedowski, J. 1978. Vegetación de México. Editorial Limusa, México.

Toledo, V. M. 1992. What Is Ethnoecology? Origins, Scope, and Implications of a Rising Discipline. Etnoecologica 1:5-21.

Vázquez G., J. A., R. Cuevas G., T. S. Cochrane, H. H. Iltis, F. J. Santana M., and L. Guzmán H. 1995. Flora de Manantlán. Sida, Botanical Miscellany, Fort Worth, TX.

Wilson, T. 2010. The Culture of Mexican Migration. Critique of Anthropology 30:399-420. DOI:10.1177/0308275X10382728.

Zitnow, J. D. 1990. A Comparison of Time Ojibway Adolescents Spent with Parents/Elders in the 1930s and 1980s. American Indian and Alaska Native Mental Health Research 3:7-16.

Zonneveld, I. S. 1989. The Land Unit. A Fundamental Concept in Landscape Ecology and These Applications. Landscape Ecology 3:67-86. 